\title{
Electrophoretic morphology of gamma globulins in cerebrospinal fluid of multiple sclerosis and other diseases of the nervous system
}

\author{
E. C. Laterre, M.D., A. Callewaert, M.D., \\ J. F. Heremans, M.D., and Z. Sfaello, M.D.
}

\begin{abstract}
Since the first studies of Kabat and coworkers $^{1}$ in 1942 , showing the rise of cerebrospinal fluid (CSF) gamma globulins in patients with multiple sclerosis (MS), several authors have become interested in studying this phenomenon in a variety of neurological diseases including MS. Different techniques have been employed (for example, electrophoresis on different supporting media ${ }^{2-20}$ and chemi$\mathrm{cal}^{21-26}$ and immunochemical determination $\left.^{27-35}\right)$, the significance of the results has not been fully appreciated, and the data have sometimes been inconclusive.

Study of the literature devoted to this subject is difficult because the selection of patients has varied and because clinical criteria have varied from one author to the next.

Few authors have employed more than one technique on the same CSF sample except to compare the colloidal curves ${ }^{5,8,9,10,25,28}$ to one of the newer techniques. It is clear that there is need for reevaluation of existing literature.

The present work is based on results obtained by agar gel electrophoresis and is concerned with a correlation between clinical parameters and different electrophoretic patterns of CSF proteins.
\end{abstract}

\section{MATERIALS AND METHODS}

Patient population. We reviewed the records of 2,043 patients who had been admitted to the Neurological Department of the University Clinics and in whom CSF protein electrophoresis was performed. In 323 patients, the diagnosis was multiple sclerosis, designated as either definite, probable, or possible. The other patients were assigned to one of the diagnostic categories listed in Table 1.

The diagnoses were based on clinical examination and technical procedures such as myelography, pneumoencephalography, arteriography, cerebral scintigraphy, electroencephalography, and routine CSF examination. The results of CSF protein electrophoresis were not considered in making the diagnosis. The different clinical and laboratory data concerning these cases of MS were plotted on IBM cards.

Tentative correlations were established between electrophoretic patterns of CSF proteins and the duration and course of the disease, degree of disability, and diagnostic category, as well as the CSF cell count and total protein content. No attempt was made to categorize

From the Laboratory of Neurochemistry and Department of Experimental Medicine, University of Louvain, Belgium This work was supported in part by the Fonds de la Recherche Scientifique Medicale.

Submitted for publication Oct. 5, 1969; resubmitted Jan. 28, 1970; accepted Feb. 16, 1970.

Dr. Laterre's address is Department of Neurology-Neurosurgery, University Hospital St. Raphael, Voer des Capucins, 35, Kapucijnenvoer, Louvain, Belgium. 
TABLE 1

DIAGNOSTIC CATEGORIES

\begin{tabular}{|c|c|c|c|c|c|c|c|}
\hline & $\begin{array}{l}\text { Num- } \\
\text { ber } \\
\text { of } \\
\text { cases }\end{array}$ & $\begin{array}{l}\text { Gamma } \\
\text { type }\end{array}$ & $\%$ & & $\begin{array}{l}\text { Num- } \\
\text { ber } \\
\text { of } \\
\text { cases }\end{array}$ & $\begin{array}{l}\text { Gamma } \\
\text { type }\end{array}$ & $\%$ \\
\hline Multiple sclerosis & 323 & 254 & 78.6 & \multirow{2}{*}{$\begin{array}{l}\text { Tumors, hydrocephalus, and in- } \\
\text { creased intracranial pressure }\end{array}$} & \multirow{2}{*}{225} & \multirow{2}{*}{10} & \multirow{2}{*}{4.4} \\
\hline Inflammatory diseases of CNS & 144 & 57 & 39.6 & & & & \\
\hline \multirow{3}{*}{$\begin{array}{l}\text { Encephalitis and meningoen- } \\
\text { cephalitis of presumed or } \\
\text { proved viral origin }\end{array}$} & & & & Intracranial tumor & 147 & 5 & \\
\hline & & & & Intraspinal tumor & 36 & 0 & \\
\hline & 40 & 14 & & Hydrocephalus and & & & \\
\hline \multirow{2}{*}{$\begin{array}{l}\text { Bacterial meningitis or asep- } \\
\text { tic meningitis and abscess }\end{array}$} & & & & meningomyelocele & 26 & 3 & \\
\hline & 67 & 22 & & Pseudotumor cerebris & 7 & 0 & \\
\hline Poliomyelitis & 7 & 1 & & Meningeal infiltrates of & & & \\
\hline Neurosyphilis & 19 & 10 & & maligrant origin & 9 & 2 & \\
\hline Toxoplasmosis & 3 & 2 & & & & & \\
\hline $\begin{array}{l}\text { Subacute sclerosing panen- } \\
\text { cephalitis }\end{array}$ & \multicolumn{3}{|c|}{8} & Vascular disorders & 195 & 4 & 2.0 \\
\hline Degenerative diseases of CNS & 321 & 11 & 3.4 & $\begin{array}{l}\text { Acute cerebrovascular } \\
\text { accident }\end{array}$ & 37 & 1 & \\
\hline \multirow{4}{*}{$\begin{array}{l}\text { Amyotrophic lateral sclerosis } \\
\text { Syringomyelia } \\
\text { Subacute combined degenera- } \\
\text { tion of the spinal cord } \\
\text { Myelopathy of undetermined } \\
\text { origin or secondary to } \\
\text { cervical arthritis }\end{array}$} & 36 & 0 & & \multirow{2}{*}{$\begin{array}{l}\text { Chronic cerebrovascular } \\
\text { disease }\end{array}$} & \multirow{2}{*}{110} & \multirow[b]{2}{*}{0} & \\
\hline & 16 & 0 & & & & & \\
\hline & 8 & 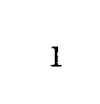 & & $\begin{array}{l}\text { Acute vascular disorder of } \\
\text { the spinal cord }\end{array}$ & 10 & 1 & \\
\hline & 170 & 9 & & Intracranial hemorrhage & 38 & 2 & \\
\hline Friedreich's ataxia & 6 & 0 & & Miscellaneous disorders & 562 & 12 & 2.1 \\
\hline $\begin{array}{l}\text { Cerebral or cerebellar de- } \\
\text { generation }\end{array}$ & 54 & 1 & & Epilepsy and syncope & 193 & 1 & \\
\hline \multirow{2}{*}{$\begin{array}{l}\text { Parkinson's disease } \\
\text { Chorea, choreoathetosis, } \\
\text { and dystonia }\end{array}$} & 12 & 0 & & $\begin{array}{l}\text { Encephalopathy of } \\
\text { various origin }\end{array}$ & 28 & 4 & \\
\hline & 19 & 0 & & $\begin{array}{l}\text { Mental and psychomotor } \\
\text { retardation }\end{array}$ & 19 & 0 & \\
\hline \multirow{2}{*}{$\begin{array}{l}\text { Radiculitis, neuritis, and } \\
\text { neuralgia }\end{array}$} & \multirow{2}{*}{273} & \multirow{2}{*}{14} & \multirow{2}{*}{5.1} & Craniocerebral trauma & 45 & 2 & \\
\hline & & & & Overdosage of drugs & 12 & $\mathbf{0}$ & \\
\hline \multirow{2}{*}{$\begin{array}{l}\text { Trigeminal neuralgia } \\
\text { Sciatic neuropathy, herniated } \\
\text { lumbar disk, and lumbar } \\
\text { pain }\end{array}$} & 14 & \multicolumn{2}{|l|}{0} & Arachnoiditis & 10 & 0 & \\
\hline & 148 & 5 & & $\begin{array}{l}\text { Optic neuritis and } \\
\text { neuromyelitis optica }\end{array}$ & 13 & 3 & \\
\hline Brachial neuritis & 17 & 1 & & Muscle disease & 7 & 0 & \\
\hline Polyneuropathy & 50 & 0 & & Headache, dizziness, and & & & \\
\hline Guillain-Barré syndrome & 28 & 8 & & psychiatric disorder & 219 & 2 & \\
\hline Cranial nerve disorder & 16 & 0 & & Nonneurological disease & 16 & 0 & \\
\hline
\end{tabular}

the patients with regard to the state of activity of the disease since it is not our practice to perform lumbar punctures on patients during remissions.

Some criteria of classification require explanation. The diagnosis of MS was designated as definite if all the classical criteria were ful- filled, i.e., age at onset between 20 and 40 years, symptoms indicative of multiple lesions, and fluctuating course. The diagnosis was recorded as probable if one of these features was only doubtfully present. If two characteristics were lacking, the diagnosis of MS was reported as merely possible. 
Patients were categorized as follows, in a somewhat arbitrary way:
Grade I: Patient able to manage him- self in every respect; normal social and professional life

Grade II: Patient unable to practice his profession, whatever its nature, but walking unaided and not requiring nursing assistance

Grade III: Patient entirely incapacitated, needing help for everything, bedridden, and incontinent.

Laboratory methods. After microscopical examination, cell counts, and centrifugation, the total protein concentration of the CSF samples was determined by the trichloracetic acid method of Meulemans. ${ }^{36}$ Four to five milliliters of CSF were concentrated 30 to 50 times at $4^{\circ} \mathrm{C}$. by means of positive-pressure ultrafiltration, using the commercial device M.D. 35-15 from Membranfilter Gesellschaft, Göttingen, Western Germany. All concentrates were adjusted to approximately the same protein content. Electrophoresis of the concentrates was carried out in agar gel according to Wieme. ${ }^{37}$ After desiccation and staining with amido black, the electrophoretic strips were analyzed by visual inspection, mainly with respect to characteristic morphological patterns of gamma globulins, and classified into 3 categories: ${ }^{15}$ "normal type", "gamma type", and "transudative type", which were defined as follows:

The normal type of pattern includes a prominent prealbumin band and a weakly staining gamma zone which is conspicuous by its homogeneity, except for a cathodal reinforcement due to the presence of the "post-gamma" proteins. ${ }^{38}$ The gamma type differs from the normal only by the quantitative importance and, particularly, the electrophoretically heterogeneous appearance of the gamma globulin zone. In the transudative type essentially corresponding to massive admixture of serum proteins to CSF, the prealbumin band is diluted out of the pattern, and the albumin zone and alpha-1 and alpha-2 globulin bands assume increasing importance, whereas the gamma globulin zone, although quantitatively abnormally prominent, retains its normal homogeneous appearance.

The same three types were distinguished with equal ease by other methods of analysis, such as electrophoresis on acrylamide-agarose gels, ${ }^{39}$ gel chromatography on Sephadex, or immunoelectrophoresis, ${ }^{40}$ all of which were

TABLE 2

CLINICAL PARAMETERS AND ROUTINE LABORATORY RESULTS CORRELATED TO CSF GAMMA PATTERN

\begin{tabular}{|c|c|c|c|c|c|c|c|}
\hline & $\overbrace{<1 \text { year }}^{\text {Duration of } d}=$ & disease $_{-1}$ year & $\begin{array}{c}\text { Course of } \\
\begin{array}{c}\text { Remission and } \\
\text { relapse }\end{array}\end{array}$ & $\begin{array}{l}\text { disease } \\
\text { Progressive }\end{array}$ & Grade & $\underset{I I}{e}$ of disa & III \\
\hline Number of cases & 85 & 238 & 174 & 149 & 117 & 158 & 48 \\
\hline Gamma type & 64 & 190 & 137 & 117 & 86 & 126 & 42 \\
\hline $\begin{array}{l}\text { Percent gamma } \\
\text { type }\end{array}$ & 75.3 & 79.8 & 78.7 & 78.5 & 73.5 & 79.7 & 87.5 \\
\hline Significance & \multicolumn{2}{|c|}{$0.50>p>0.30$} & \multicolumn{2}{|c|}{$\mathrm{p}=0.99$} & $0.30>\mathrm{p}>0.20$ & \multicolumn{2}{|c|}{$\begin{aligned} 0.30>\mathrm{p}>0.20 & \\
0.05 & \end{aligned}$} \\
\hline & \multicolumn{3}{|c|}{ Diagnostic categories } & \multicolumn{2}{|c|}{$\begin{array}{c}\text { CSF cell count per cu. } \mathrm{mm} . \\
0-5\end{array}$} & \multicolumn{2}{|c|}{$\overbrace{(\mathrm{mg} . / 100 \mathrm{ml} .)}^{\text {CSF total protein }}$} \\
\hline Number of cases & 121 & 118 & 84 & 243 & 80 & 916 & 107 \\
\hline Gamma type & 91 & 90 & 73 & 183 & 71 & 165 & 89 \\
\hline $\begin{array}{l}\text { Percent gamma } \\
\text { type }\end{array}$ & 75.2 & 76.3 & 86.9 & 75.3 & 88.8 & 76.4 & 82.2 \\
\hline Significance & \multicolumn{3}{|c|}{ 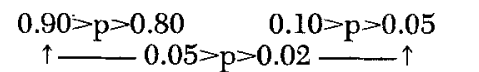 } & \multicolumn{2}{|c|}{$\mathrm{p}=0.01$} & \multicolumn{2}{|c|}{$0.20>p>0.10$} \\
\hline
\end{tabular}


employed to confirm the data of agar gel electrophoresis.

\section{RESCLTS}

Multiple sclerosis. [1] Our MS patient group included 151 men and 172 women.

2] The age of onset was between 20 and 40 for $215(67 \%)$ of the 323 patients.

3] No differences were found between a

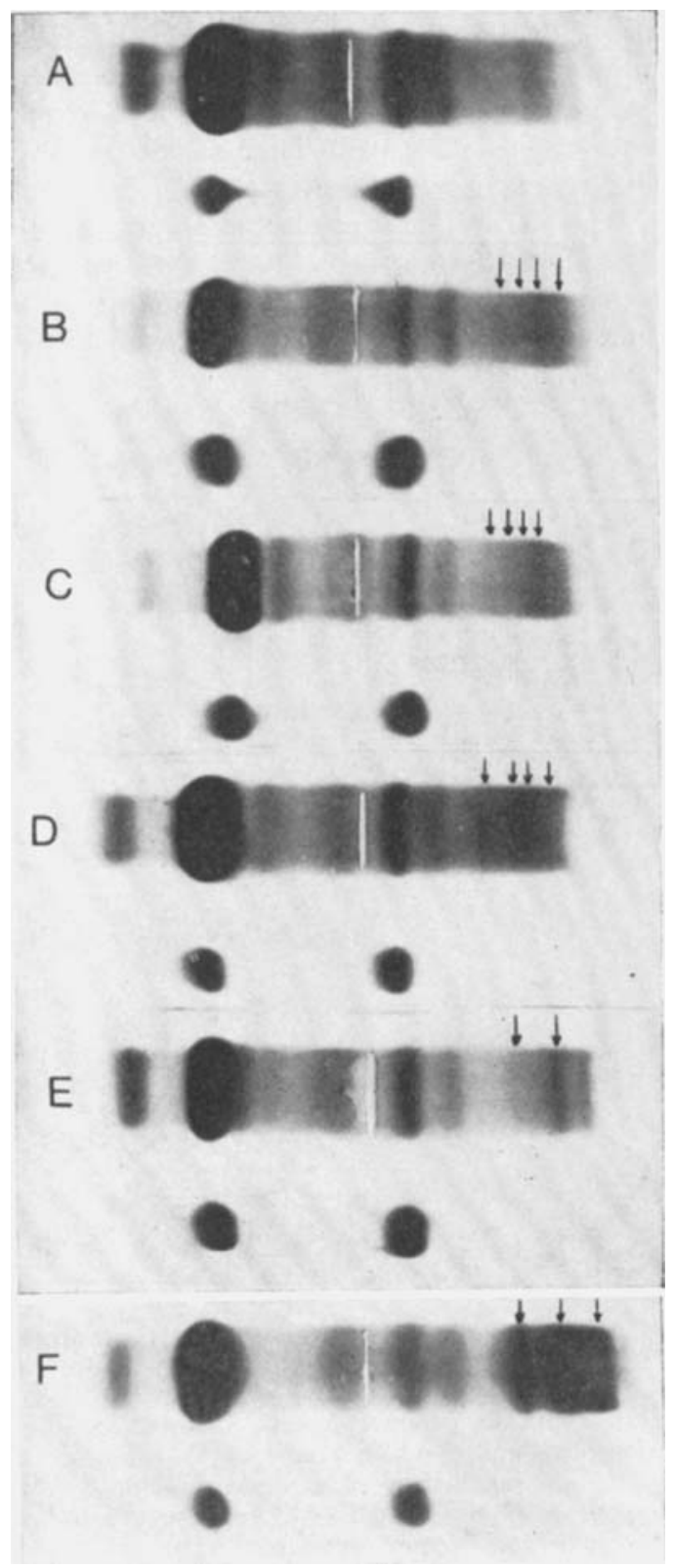

short $(<1$ year) and a long duration $(>1$ year) of disease and the frequency of changes in electrophoretic pattern of CSF gamma globulins (Table 2).

4] The course of disease fluctuated in $\mathbf{1 7 4}$ patients and was progressive, i.e., without sharp remission, in 149. The figure of 149 for the progressive course may seem excessive. However, among these were included all patients for whom the evolution was shorter than one year because the fluctuating character of the disease is very difficult to ascertain during the first year after onset. As shown in Table 2 , there was no correlation between the course of disease and the CSF pattern.

5] On the other hand, there was a good correlation between the degree of disability and the CSF protein pattern when Grade $I$ and Grade III were compared ( $p=0.05$ ).

6] A good correlation also existed between the diagnoses rated as possible and definite and the morphological pattern of gamma globulins $(0.05>\mathrm{p}>0.02)$.

7] The CSF cell count and changes of gamma globulins also gave a good correlation $(\mathrm{p}=0.01)$.

8] No correlation was noted between total protein content of CSF and the electrophoretic pattern. In our studies, the critical level was fixed at $40 \mathrm{mg} . / 100 \mathrm{ml}$., but it is realized that this choice depends on the method of protein quantitation employed and the fact that the appropriate limiting value may be different in the hands of other investigators. ${ }^{1 \tilde{5}}$

Other cases. As shown in Table 1, 1,720 patients with various diseases were grouped in different categories and their records were examined in detail with special reference to the electrophoretic pattern of their CSF proteins. The absolute number of gamma-type electrophoretic patterns in CSF protein is indicated at the right side of Table 1 . The frequency of the gamma type is given for 6 major categories;

Fig. 1. Agar gel electrophoretic pattern of CSF gamma globulins in [A] normal CSF, [B], [D], and [E] MS cases, [C] sarcoidosis of CNS, and [F] subacute sclerosing panencephalitis. The garmma bands are indicated by arrows. Beneath each CSF sample, a reference mixture consisting of serum albumin and transferrin is run. 
it varied between 2 and $5.1 \%$, except for the inflammatory diseases of the central nervous system (CNS) in which it reached $39.6 \%$.

\section{DISCUSSION}

Consideration of the diagnostic value of " $r$ stricted electrophoretic heterogeneity" of pathological gamma globulins in CSF and interpretation of agar gel electrophoresis. Various authors, ${ }^{12.14,17}$ including ourselves, ${ }^{13,15,16}$ have shown that the essential feature of the gamma globulins in CSF from patients with MS and other inflammatory CNS diseases resides in the "restricted heterogeneity distribution," i.e., in the appearance of striations and discrete bands within the diffuse gamma area. Cumulative experience from more than 4,000 electrophoretic examinations, including about 500 cases of MS, has convinced us of the diagnostic importance of this pattern of discrete bands with- in the gamma globulins, which we have designated as the "oligoclonal aspect."15 It may be added that the gamma globulins giving rise to this phenomenon have always been found to belong to the IgG class. ${ }^{13}$

The limited amounts of material usually do not permit the use of conventional methods of protein fractionation and physicochemical or immunochemical analysis. It is known, however, that all such oligoclonal gamma components behave identically during gel filtration on Sephadex, indicating that they all belong to the $7 \mathrm{~S}$ class of immunoglobulin molecules. ${ }^{17}$ In particular, these findings make it clear that one is not dealing with immunoglobulin fragments arising by proteolysis.

The phenomenon of electrophoretic heterogeneity should not be confused with the antigenic heterogeneity which is apparent on some immunoelectrophoretic CSF patterns that show

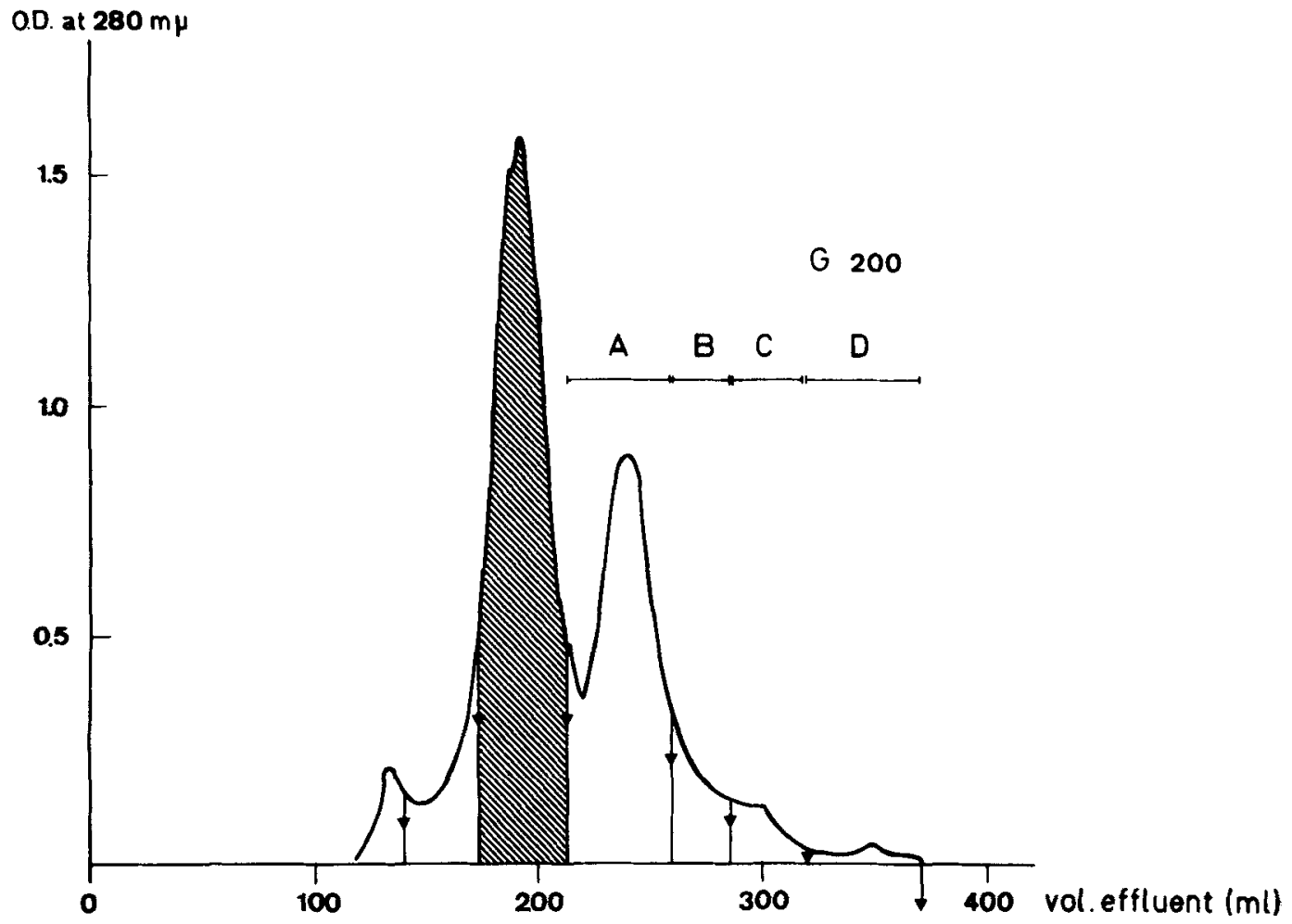

Fig. 2. Gel chromatography by Sephadex G 200 of $1.5 \mathrm{ml}$. of concentrated CSF (protein content:7.3 gm. $/ 100 \mathrm{ml}$.) from a patient with subacute sclerosing panencephalitis. Column measured 100 by $2.5 \mathrm{~cm}$. Elution rate was $12 \mathrm{ml}$. per hour and $2-\mathrm{ml}$. fractions of the effluent were collected. The second peak (shaded area) is composed mainly of gamma globulins (7 S). Albumin and transferrin are the prinicipal components of the third peak (A). The following fractions of the curve $(\mathrm{B}, \mathrm{C}$, and $\mathrm{D})$ contain low molecular weight proteins. 
a parallel duplication of the gamma G-precipitin line. ${ }^{13}$ The latter feature, which may also occasionally be observed in normal serum provided use is made of appropriate antisera, ${ }^{41}$ merely reflects the fact that immunoglobulins represent a mixture of two antigenically distinct populations differing by their type (kappa or lambda) of light polypeptide chains. ${ }^{42,43}$ The fact that the gamma $G$ line is more conspicuously duplicated in certain CSF samples than in others is due to an imbalance of the kappa:lambda ratio of the immunoglobulins present and bears no causal relationship to electrophoretic heterogeneity. Both phenomena are indirectly linked, however, in that they represent an upsetting of the ratio between the different components of the normal immunoglobulin mixture, owing to overrepresentation of immunoglobulins (i.e., antibodies) which are synthesized in situ. Yet a third reflection of the same fundamental imbalance is found in the abnormal distribution of the different electrophoretic subgroups which can be distinguished by means of electrophoresis in urea-containing alkaline buffers of the heavy polypeptide chains separated from CSF immunoglobulins in cases of multiple sclerosis. ${ }^{17}$ It is possible that a similar interpretation applies to older reports on the heterogeneity of CSF immunoglobulins on the faith of data gathered by means of chromatography on ion exchangers. ${ }^{44}$

For diagnostic purposes, this morphological aspect of gamma globulins is much more important than their absolute or relative values and is independent of the latter. It is for this reason that the precise quantity of gamma globulins in CSF, as determined by chemical or immunochemical means or photometric scanning of electrophoretic strips, has always seemed of secondary importance to us. In some cases, the absolute or relative level of CSF gamma globulins may be normal while the "restricted electrophoretic heterogeneity" pattern is present.

The visual inspection of electrophoretic plates is not only sufficient, but it cannot be replaced by the best mechanical scanning methods. This was also emphasized by Link. ${ }^{17}$ It is necessary, of course, to have a great deal of experience in reading electrophoretic plates because, in the gamma zone, other proteins are present which can confuse the inexperienced observer. ${ }^{17,38}$ This is the case for the postgamma ${ }^{15,38}$ (or gamma trnce ) protein which develops an increased mobility with storage and aging of the sample. Originally, the electrophoretic mobility of the postgamma protein is slower than the mobility of the gamma globulins. However, upon storage, this mobility increases and becomes approximately that of the gamma globulins which may thus be mimicked by the modified protein. ${ }^{45} \mathrm{On}$ the other hand, Link ${ }^{\mathbf{1 7}}$ has clearly shown that the zone comprised between the T-protein (transferrin II) and gamma globulins, is occupied mainly by beta trace protein which characteristically shows 4 distinct bands. Finally, the "restricted electrophoretic heterogeneity" of gamma globulins may not be clear if the CSF is too much or not sufficiently concentrated.

In cases of intrathecal inflammatory reactions, it is in the slow part of gamma zone (gamma-4 of Lowenthal and associates ${ }^{12,14}$ ) that the pathological IgG bands are found which sometimes overflow toward the anodic or cathodic regions (Fig. 1). Concerning the supporting medium used for electrophoresis, it would seem that agar gel is one of the most convenient. The resolution in agar gel is superior to that on paper, and the gel also permits the use of a relatively small quantity of $\mathrm{CSF}$ as compared to paper. Other supporting media for electrophoresis may have superior resolutive power compared to agar gel, i.e., starch geili9 and acrylamide gel; ${ }^{20}$ however, for the analysis of the gamma zone, these techniques are less desirable because of the interference of other proteins in this area (alpha-2 macroglobulin, haptoglobin, and so forth). The example shown in Figures 2, 3, and 4 is illustrative of this technical problem. It shows, in a case of subacute sclerosing panencephalitis, the resolution of gamma globulins in acrylamide-agarose (Fig. 3) and in agar gel (Fig. 4). In acrylamide-agarose, the bulk of gamma globulins is concentrated in a homogeneous mass, except for one band of faster mobility (arrow); in agar gel, four gamma bands (arrows) are clearly visible.

Proportion of multiple sclerosis cases with abnormal levels or characteristic morphological pattern of CSF gamma globulins. Schneck and 


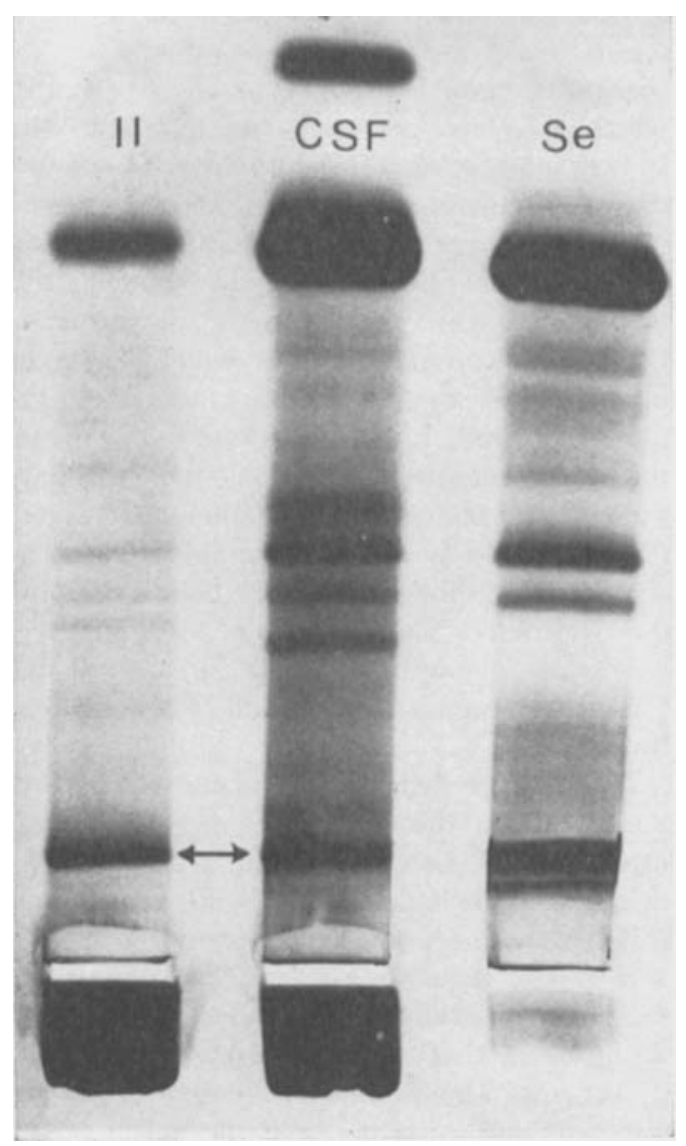

Fig. 3. Acrylamide-agarose gel electrophoresis of the second (II) chromatography peak (shaded area of Figure 2), the whole CSF, and the serum (Se) of the patient. The bulk of gamma globulins is concentrated in a cathodic homogeneous mass, except for one band of faster mobility (arrow).

Claman $^{35}$ have recently made a survey of the literature on this subject and have analyzed the methods employed. The same comparison has been made by one of us. ${ }^{16}$ The percentage of qualitative changes or quantitative rises of gamma globulins is very variable and fluctuates from $40^{9}$ to $93 \%^{3}$ but generally is situated between 50 and $80 \% .^{5,7,8,13,14,16,25,27,28,31,32,35}$ Comparisons of colloidal methods with electrophoretic, immunochemical, and chemical techniques of estimation of gamma globulins have usually been vastly in favor of the latter. $\tilde{.}, 9,25,28$

Discordant findings, however, are the reports of high percentages of positive results with the mastix curve in the hands of Bergmann and co-workers ${ }^{8}$ and the very low positive results with paper electrophoresis in the hands of Bradshaw. ${ }^{9}$

In the present study, $78.6 \%$ of all MS patients have shown clear-cut changes in the CSF gamma globulin pattern. The percentage ranges between 75.2 and $86.9 \%$, depending upon the diagnostic category. The high incidence of positive results in MS cases and the low incidence in other diseases (except for the group of inflammatory disorders) emphasizes the diagnostic value of the method employed.

It should be emphasized that, for the purpose of clinical diagnosis, the absolute or relative levels of gamma globulins in CSF are less important than is the electrophoretic morphology. With the agar gel technique, the quantitative or qualitative modifications of CSF gamma globulins are sharply outlined. The laboratory answer is definite and there is no overlap between the normal and pathological ranges as is sometimes the case with other methods.

Frequency of CSF gamma globulin changes in relation to the duration and course of the disease and to the evolutive state of disease at the time of lumbar puncture. Yahr et al. ${ }^{28}$ were unable to find any correlations between these clinical parameters, on the one hand, and the incidence of rises of gamma globulins in the CSF on the other. Schapira and Park, ${ }^{6}$ Ivers et al., ${ }^{5}$ Tourtellotte, ${ }^{31}$ Tourtellotte and Parker, ${ }^{32}$ Prineas et al., ${ }^{26}$ and Laterre ${ }^{16}$ are in accord with Yahr et al.28

Our own present results agree with these conclusions. It is necessary to bear in mind that these results are merely statistical in nature. Few patients have had repetitive lumbar punctures throughout the course of their disease. Bradshaw ${ }^{9}$ disagrees with these conclusions and is of the opinion that a fairly close

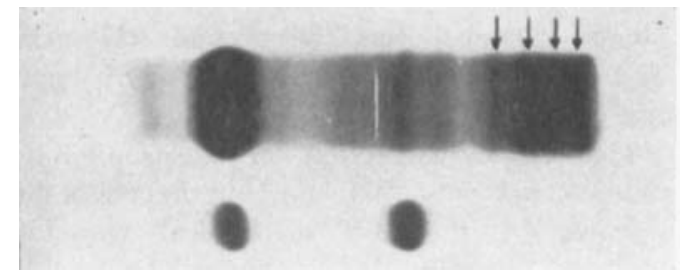

Fig. 4. Agar gel electrophoresis of whole $\mathrm{CSF}$ proteins from the same case of subasute sclerosing panencephalitis. Four gamma bands (arrows) are clearly visible. 
relationship exists between the elevation of the CSF gamma globulins and the clinical activity of MS.

Frequency of CSF gamma globulin changes in relation to degree of disability and diagnostic category. We have noted a good correlation between these two clinical parameters and the changes of CSF gamma globulins, in agreement with Yahr et al., ${ }^{28}$ Ivers et al., ${ }^{5}$ Schapira and Park, ${ }^{6}$ and Prineas et al., ${ }^{26}$ who all observed significant differences of the same order. Bergmann et al. ${ }^{8}$ did not share this opinion. The relationships observed by Yahr et al., ${ }^{28}$ Tourtellotte, ${ }^{31}$ Prineas et al., ${ }^{26}$ and ourselves between the cell count and gamma globulin changes are understandable since gamma globulins are produced by lymphocytes and related cells.

Frequency of CSF gamma globulin changes in other neurological diseases. It is not at all surprising to find similar electrophoretic patterns of gamma globulins in inflammatory diseases of the nervous system. In our group, a gamma pattern was present in $39.6 \%$ of the cases studied. In the other groups of diseases, the frequency of gamma globulin changes ranged from 2 to $5.1 \%$ (Table 1 ). This incidence suggests that the particular morphological pattern of gamma globulins is not specific for or pathognomonic of MS. In any intrathecal inflammatory process it is possible to find the same morphology. On the other hand, only a few of our patients came to autopsy and, therefore, the possibility of some diagnostic errors must be taken into account.

\section{SUMMARY}

CSF protein electrophoresis in agar gel was performed in 2,043 patients. Among them, 323 patients were classified as having MS. The essential feature of the gamma globulins in CSF from MS patients and other inflammatory CNS diseases resided in their restricted heterogeneity distribution. This peculiar electrophoretic pattern occurs in 75.2 to $86.9 \%$ of MS patients, depending upon the diagnostic category (possible, probable, or definite). The differences were significant. In MS patients there was also a positive correlation between the degree of disability and the frequency of gamma pattern when Grade I and Grade III were compared, but no correlation was found between the du- ration and course of the disease on the one hand and the CSF gamma globulin changes on the other hand.

In the other patients, this frequency varied between 2 to $5.1 \%$, except for the group with inflammatory CNS diseases in which it reached $39.6 \%$. The diagnostic value of the method employed is discussed and emphasized.

The expert assistance of Miss $H$. Heulle is gratefully acknowledged.

\section{REFERENCES}

1. KABAT, E. A., MOOFE, D. H, and LANDOW, H.: An electrophoretic study of the protein components in cerebrospinal fluid and their relationship to the serum proteins. J. clin. Invest. 21:571, 1942 .

2. Roboz, E., hess, W. C., and Forster, F. M.: Quantitative determination of gamma globulin in cerebrospinal fluid: Its application in multiple sclerosis. Neurology (Minneap.) $3: 410,1953$.

3. volk, B. W., SAIFER, A., RABINER, A., and oRESkEs, 1 .: "Protein profile" in multiple sclerosis. Arch. Neurol. Psychiat. (Chic.) 73:66, 1955.

4. BAUER, H.: Zur Frage der Identität der Liquorproteine mit den Eiweisskörpern des Blutserums. T. Besonderheiten der Liquorproteine hinsichtlich der Vorfraktion, der Gamma-Globuline und der proteingebundenen Lipide. Dtsch. Z. Nervenheilk. 175:354, 1956.

5. IVERS, R, R., MC KENZIE, B, F, MCGUCKIN, w. $F$, , and GoldsteIN, N. P.: Spinal fluid gamma-globulin in multiple sclerosis and other neurologic diseases: Electrophoretic pattern in 606 patients. J. Amer. med. Ass. $176: 515,1961$.

6. SCHAPMA, K., and PARK, D. C.: Gammaglobulin studies in multiple sclerosis and their application to the problem of diagnosis. J. Neurol. Neurosurg. Psychiat. 24: 121,1961 .

7. BElanger, c., LAROChE, F., POUDRIER, C., and MarTIN, J.: Etude sur le liquide céphalo-rachidien par l'électrophorèse sur papier. Laval Méd. 33:797, 1962.

8. BERGMANN, L., GILLAND, O., OLANDERs, s,, and SVENNERHoLM, $\mathrm{z}$.: Clinical profile and paper-electrophoresis in multiple sclerosis. Acta neurol. scand. 40 (suppl. 10):33, 1964.

9. BRADSHAw, P.: The relation between clinieal activity and the level of gammaglobulin in the cerebrospinal fluid in patients with multiple sclerosis. J. Neurol. Sci. $1: 374,1964$

10. Cosgrove, J. B. R., and AgIUS, P.: Studies in multiple sclerosis: II. Comparison of the beta-gamma globulin ratio, gamma globulin elevation, and first-zone colloidal gold curve in the cerebrospinal fluid. Neurology (Minneap.) 16:197, 1966.

11. BERGMANN, I., and GILLAND, o.: Monosymptomatic gamma globulin elevation in CSF as an indicator of multiple sclerosis. Acta. neurol. scand. 44:228, 1968 .

12. LOWENTHAL, A., VAN SANDE, M., and KARCHER, D.: The differential diagnosis of neurological diseases by fractionating electrophoretically the CSF-globulins. J. Neurochem. 6:51, 1960.

13. LATERRE, E. C., HEREMANS, J. F., and DEMANET, G.: La pathologie des protéines du liquide céphalorachidien: Etude électrophorétique et immunoélectrophorétique (600 observations). Rev. neurol. 107:500, 1962 .

14. Lowenthal, A.: Agar Gel Electrophoresis in Neurology. Amsterdam: Elsevier Publishing Co., 1965.

15. Laterre, E. c.: Les Protéines du Liquide CéphaloRachidien à l'etat Normal et Pathologique. Brussels: Arscia; Paris: Maloine, 1965.

16. LAtekre, $\mathbf{E}$. C.: Les gammaglobulins du liquide céphalo-rachidien dans la sclérose en plaques. Acta neurol. belg. $66: 305,1966$. 
17. LINK, M.: Immunoglobulin $\mathrm{G}$ and low molecular weight proteins in human cerebrospinal fluid. Chemical and immunological characterization with special reference to multiple sclerosis. Acta neurol, scand. 43(suppl. $28): 1,1967$

18. erackennIDGe, C. J.: Cerebrospinal fluid protein fractions in health and disease. J. clin. Path. 15:206, 1962.

19. KUTT, H., MC DOWELL, F., GHAPMAN, $x$, PERT, J., and HURWITZ, L. J.: Abnormal protein fractions of cerebrospinal fluid demonstrated by starch gel electrophoresis. Neurology (Minneap.) 10:1064, 1960.

20. CONNINGHAM, y, R.: Analysis of native cerebrospinal fluid by the polyacrylamide disc electrophoresis technic. J. clin. Path. 17:143, 1964.

21. zregler, D. K., and ross, G.: Cerebrospinal fluid gamma globulin as a diagnostic test for multiple sclerosis. Neurology (Minneap.) 5:573, 1955.

22. papadopoulos, N. M., hess, W. C., o'doherty, D. o., and MCLANE, J. E.: A procedure for the determination of cerebrospinal fluid total protein and gammaglobulin in neurologic disorders. Clin. Chem. 5:569, 1959.

23. HANOK, A.: A micro-modification of a method for the measurement of globulin in cerebrospinal fluid and its application in diagnosis of multiple sclerosis. J. Lab. clin. Med. 57:42, 1961 .

24. Foster, J. B., and HorN, D. B.: Multiple sclerosis and spinal-fluid gamma-globulin. Brit. med. J. 1:1527, 1962.

25. Castaigne, P., cambier, J., and schuller, e.: Dosage des protéines totales et de certaines globulines du líquide céphalo-rachidien. II. Dosage des $\gamma$-globulines du liquide céphalo-rachidien. Rev. franc. Etud. clin. biol. 10:534, 1965 .

26. PRINEAS, J., TEASDALE, G., LATNER, A. L., and MILLER, H.: Spinal-fluid gamma-globulin and multiple sclerosis. Brit. med. J. 2:922, 1966.

27. KABAT, E. A., FREEDMAN, D. A., MURRAY, w. F., and coldstein, N. P.: A study of the crystalline albumin gammaglobulin and total protein in the cerebrospinal fluid of one hundred cases of multiple sclerosis and in other diseases. Amer. J. med. Sci. 219:55, 1950.

28. YAHR, M. D., GOLDENSOHN, s. s., and KABAT, E. A.: Further studies on the gammaglobulin content of cerebrospinal fluid in multiple sclerosis and other neurological diseases. Ann. N.Y. Acad. Sci. 58:613, 1954.

29. HARTER, D. H., YAHR, M. D., and KABAT, E. A.; Neurological diseases with elevation of cerebrospinal fluid gamma globulin: A critical review. Trans, Amer. neurol. Ass. 87:210, 1962 .

30. SIBLEY,,$A^{\prime}$, and wURz, $L$, Immunoassay of cerebrospinal fluid gamma-globulin. Arch. Neurol. (Chic.) $9: 386$, 1963 .
31. Tountellotte, w. w.: Multiple sclerosis and cerebrospinal fluid. Med. Clin. N. Amer. 47:1619, 1963.

32. Tourtellotte, $w$. w., and PARKER, J. A.: Distribution and subfractionation of immunoglobulins in patients with multiple sclerosis. Trans. Amer, neurol. Ass, 90: $107,1965$.

33. LATERRE, E. C., heUlle, H., MANCiNI, G., and hereMANS, J. F.: Application de l'immunodiffusion radiaire simple en gel d'agar au dosage des protéines du liquide céphalo-rachidien. In: Protides of the Biological Fluids. Edited by H. Peeters. Amsterdam: Elsevier Publishing Co., 1966, p. 227.

34. hartley, F. F., Mehrill, D. A., and Claman, H. N.: Quantitation of immunoglobulins in cerebrospinal fluid. Arch. Neurol. (Chic.) 15:472, 1966.

35. SCHNECK, S. A., and CLAMAN, H. N.: CSF immunogiobulins in multiple sclerosis and other neurologic diseases: Measurement by electroimmunodiffusion. Arch. Neurol. (Chic.) 20:132, 1969.

36. meulemans, o.: Determination of total protein in spinal fluid with sulphosalicylic acid and trichloracetic acid. Clin. chim. Acta 5:757, 1960.

37. wIEME, R. J.: Studies on Agar Gel Electrophoresis. Brussels : Arscia, 1959.

38. Laterhe, E. C., and heremans, J. F.: A note on proteins apparently "specific" for cerebrospinal fluid. Clin. chim. Acta 8:220, 1963.

39. UnIEL, J.: Méthode d'électrophorèse dans des gels d'acrylamide-agarose. Bull. Soc. Chim. biol. (Paris) 48:969, 1966

40. SCHEIDEgGer, J. J.: Une micro-méthode de l'immunoélectrophorèse. Int. Arch. Allergy 7:103, 1955.

41. edELMAN, G. M., HEREMANS, J. F., HEREMANS, M.-TH., and KUNKEL, H. G.: Immunological studies of human gamma globulin. J. exp. Med. 112:203, 1960.

42. MANNIK, M., and KUNKEL, H. G.: Classification of myeloma proteins, Bence Jones proteins, and macroglobulins into two groups on the basis of common antigenic characters. J. exp. Med. 116:859, 1962.

43. FAHEX, J. L., and solomoN, A.: Two types of gamma myeloma proteins, beta-2A-myeloma proteins, gamma-1 macroglobulins, and Bence Jones proteins identified by two groups of common antigenic determinants. J. clin. Invest. 42:811, 1963.

44. Tourtellotte, w. w., Parker, J. A., and haeher, $A$. F.: Subfractionation of multiple sclerosis gamma globulin. Z. Immun.-Forsch, 126:85, 1964.

45. LATEhre, E. C.: L'électrophorèse en agar des protéines du liquide céphalo-rachidien: Sémiologie de la zone gamma. Acta neurol. belg. 66:289, 1966. 


\section{Neurology}

Electrophoretic morphology of gamma globulins in cerebrospinal
fluid of multiple sclerosis and other diseases of the nervous system

E. C. Laterre, A. Callewaert, J. F. Heremans, et al.

Neurology 1970;20;982

DOI 10.1212/WNL.20.10.982

This information is current as of October 1, 1970

Updated Information \&

Services

Citations

Permissions \& Licensing

Reprints including high resolution figures, can be found at:

http://n.neurology.org/content/20/10/982.full

This article has been cited by 1 HighWire-hosted articles:

http://n.neurology.org/content/20/10/982.full\#\#ot herarticles

Information about reproducing this article in parts (figures,tables) or in its entirety can be found online at:

http://www.neurology.org/about/about_the_journ al\#permissions

Information about ordering reprints can be found online:

http://n.neurology.org/subscribers/advertise

Neurology ${ }^{\circledR}$ is the official journal of the American Academy of Neurology. Published continuously since 1951, it is now a weekly with 48 issues per year. Copyright (C) 1970 by the American Academy of Neurology. All rights reserved. Print ISSN: 0028-3878. Online ISSN: 1526-632X.

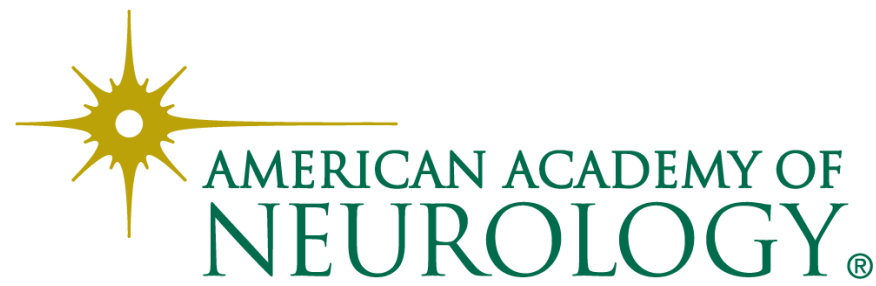

